\title{
The synchrony of temporary young workers
}

\author{
Employment discontinuity, \\ income discontinuity and new \\ social inequalities in Italy
}

\section{Sonia Bertolini and Valentina Moiso}

\section{I Introduction and theoretical approach}

In Italy, young people often have to deal with both employment and income discontinuity. This co-existence is characteristic of Italy more than any other European country because it encompasses the employment experiences of young workers with a variety of skill levels, including those with higher qualifications, and it lasts over time. In other European countries, young people can rely on public support during unemployment even if they have had precarious jobs (e.g. Germany or Sweden). This condition represents an area of social risk that has not been fully conceptualized as such, and which we posit as the object of this chapter. In particular, the chapter aims to analyse some of the coping strategies that young Italians use to deal with income discontinuity, given the framework of opportunities and constraints that informs their actions.

Young people's coping strategies, relative to representations, meanings and feelings were investigated through semi-structured interviews on two different samples of 100 young people in total, drawing from the projects 'Online training for the development of women's managerial skills. Women Online' and 'Except - Social Exclusion of Youth in Europe: Cumulative Disadvantage, Coping Strategies, Effective Policies and Transfer'. ${ }^{1}$ A qualitative analysis allows for a more in-depth study of the different nuances of the problem. The study was concerned with both self-employed workers and workers with atypical contracts, as well as those with problems of precariousness and low labour-market attachment, and with different levels of education. What they had in common is that they were all lacking a so-called typical contract, in the sense of being permanent, dependent and full-time, and the workers being young (18-30 years). Being atypical on the Italian labour market and young at the same time are two conditions that in Italy, as in other European countries, are strongly linked. Comparative research (Mills and Blossfeld, 2003; Blossfeld et al., 2011a) has shown that young Europeans are increasingly subject to forms of temporary employment. They are at higher risk of unemployment and take longer to reach stable and continuous working conditions. This has led to the postponement of important decisions in their private lives and in the transition to adulthood. 
Our starting point is that young Italians leave the parental home much later than their counterparts in any other European country, and that the length of postponement and the effects on other life domains depend strictly on the institutional context. Institutional filters can mediate young people's economic risks, leading to significant cross-national variations in the degree to which the life courses and career paths of individuals become insecure and unstable (Blossfeld et al., 2011a, 2011b; Bertolini et al., 2014).

Some institutional changes that have occurred in the Italian labour market and the welfare state have penalized young people. We refer to the way in which flexibility was introduced in the labour market and to the lack of flexsecurity (i.e. the lack of unemployment benefits for atypical workers). These factors intertwine with restrictions in welfare-state provision. Universal measures to sustain people during periods of unemployment have been missing in Italy for a long time. Moreover, the issue of irregular payments and delays in being paid are widespread problems among workers with atypical contracts.

In the literature, less attention has been given to the role of private solutions to the lack or discontinuity of income, or even whether financial instruments have also become crucial to the family budget (Zelizer, 1994; Fourcade and Healy, 2013; Perrin-Heredia, 2011; Lazarus and Luzzi, 2015; Ossandon, 2014). Access to money and credit is recognized as one of the new axes of inequality (Crompton, 2000; Bandelj et al., 2017). The use of credit to cover a range of expenses relating to education or health, daily living expenses or even larger purchases, such as buying a flat, are examples of the complex intertwining among public and private spheres and financial institutions that Martin calls the financialization of daily life (Deville and Seigworth, 2015; Martin, 2002; Aalbers, 2008; Montgomerie, 2009). Access to credit, for example, may be necessary not only for renting or buying a house but also for starting a business or financing training to improving one's employability. Focusing on the link between labour market position and access to financial services, the divide between atypical and typical workers becomes particularly evident in terms of limited access to credit and increased $\operatorname{costs}^{2}$ (Langley, 2009; Lacan et al., 2009; Flaherty and Banks, 2013; Ducourant, 2014). Due to institutional and regulatory differences, the extent of this divide differs across countries. In France and Italy for example, the national system of access to credit is linked to working conditions: precarious workers do not normally have access to credit. On the contrary, in other countries such as the UK, the requirements are less tied to contractual conditions; for example, credit is granted to students and depends more on an assessment of the possibility of repaying the debt based on present and expected income. On the other hand, in this case, the risk of overindebtedness increases, especially for younger generations. The issues in accessing credit intersect with other aspects. If we look at leaving the parental home in some countries, such as Germany, where renting rather than ownership is the general pattern, almost all young people leave their family home in this way. Anticipation of this pattern therefore favours young people's transition, since it is less linked to the problem of access to credit. In the 
Italian context, where there is typically a preference for home ownership, this involves the mortgage system and the requirements for accessing credit become another important factor to be considered.

This chapter directly investigates young people's strategies and representations, taking into account their framing in the macro context that structure the opportunities they have. In the next section, we outline the links among labourmarket regulation, access to credit and housing market patterns, which are all macro variables to consider in analysing the processes through which young Italians leave the parental home and become economically autonomous. In the subsequent section, we show specific formal and informal strategies deployed by young people when facing the transition to adulthood. The Italian case is an interesting example of this transition, given the context of income instability and irregularity and a welfare state that provides low levels of formal protection.

\subsection{The Italian institutional context: income discontinuity and access to a credit system}

The Italian model for regulating the labour market was built around the centrality of subordinated employment and permanent contracts. The state regulated the relationship between the two; for example, it guaranteed payment terms and protected the worker, insofar as a citizen was able to fully enjoy rights to the welfare state. Wages were seen as a guarantee of the survival of the workforce and was the responsibility of the employer and the state (Bologna and Banfi, 2011). The entire private banking system and the private sector in general also operate on the same assumptions. For example, the access to credit is more difficult for workers with atypical contracts, the banks do not provide specific instruments taking into account the needs of people working without regularity of payments and the payment system of both salaries and bills are regulated on a monthly basis. Moreover, what is happening today is that many workers, especially young people, cannot rely on regular payments and at the same time cannot turn on public support. Irregular payments, weakness of welfare interventions, low dynamism of the labour market, especially for young people, who furthermore see a proliferation of atypical forms of contract, and lack of innovation in the bank system, these are all factors that define the specificity of the Italian case. This is a case in which young people experiment cumulative inequalities in terms of the possibility of having regular income that allow them to reach economic autonomy and a decent lifestyle (Meo and Moiso, 2018).

A deepened view of these dynamics could help to better understand them. The model based on the male breadwinner family arose from the typical contract. It was the adult male who, as head of the family, worked with a permanent contract, and the security of his income protected the rest of the family. Therefore, it was his income that was protected by the state. The wife would take care of the housework and family members, and the children were protected by the family while they were studying but also when looking for their first job. 
Salary payment and access to credit were also punctuated by the monthly salary deadlines, and the security of the permanent contract had become the criteria for access to credit. In recent years, credit has allowed many families to become home owners through mortgages on their first house since homeownership in Italy is one of the major systems of protection from financial risk and for the intergenerational transmission of assets. In addition, the state has supported this system through other elements, such as the reduction of transaction costs on the purchase of the first home and preferential value-added tax (VAT).

In the last decade, with the diffusion of precarious contracts, this system has entered into crisis. Deregulation policies have been highly selective, burdening the already disadvantaged labour market outsiders, while leaving the rights of labour-market insiders almost untouched. Given the strong protection guarantees for insiders, flexibility was selectively transferred to those people without safe labour-market anchorage, namely those entering the labour market (see Blossfeld et al., 2005, 2011b; Barbieri and Scherer, 2009), a strategy frequently referred to as flexibility at the margins (e.g. Buchholz et al., 2009).

In Italy, a rapid introduction of temporary employment contracts, combined with very low and targeted social protection, affected the life of young people differently than in other countries where such changes were slower or accompanied by higher levels of social protection (Bertolini, 2011). Furthermore, in a dual and segmented labour market, young people - with more temporary and atypical contracts - often could not access active and passive labour-market policies. This happened for two main reasons: for a long time, temporary contracts had been excluded from social labour protection, such as unemployment benefits. Moreover, workers with discontinuous working paths, mainly young people, had difficulty achieving minimum requirements to access protection. Berton and colleagues (2009) provocatively called this system Flexinsecurity. This is an important factor of dependency upon families for younger generations.

In this way, the reforms of the labour market at the turn of 2000 - the Treu Law of 1997 and Law 30 of 2003 - were directed at removing protection from those whose job and income were holding the rest of the family system together. However, this was done without shifting towards a new model, such as investing in the insertion of young men and women into the labour market. These reforms occurred alongside other processes of change. For example, family models had become increasingly complex; the gender roles of dual earners were no longer well defined, especially for young people where there was also a postponement of the traditional stages in their transition to adult life.

Finally, there was a lack of a facilitated rental policy to support the housing autonomy of young people. As stated by Rabaiotti (2011), a housing policy that encourages youth autonomy should support a low-cost and temporary solution, features that property ownership did not have. In Italy, 70\% of people were homeowners, while $17.8 \%$ were renting at market prices. However, $17 \%$ of owners had a current loan or mortgage (Banca d'Italia, 2018). In other countries, homeowners where only 53.2\% of the population, such as Germany (Sweden 68.0\%, 
the Netherlands 59.5\% and Denmark 52.7\%). These differences in housing were reflected in the ways and timings in which young people left their parental home. Some studies pointed out that the Italian youth population was excluded from the housing ladder, because of the difficulty in obtaining mortgages. Youth became a rental generation. There was a debate about the possibility of intergenerational conflict between housing poor young people and the rich elderly (Mckee and Hoolachan, 2015), especially in Northern Europe. This was intimately connected to the question of the future of the welfare-state system. In particular, leaving parental home to rent was not considered an efficient solution in countries where homeowners were predominant. This further delayed the time of departure from the family home because of the difficulty of access to credit for this part of the population. In Southern Europe, the prolonged permanence with the family was seen as a way to avoid depleting the resources of the family: you left home only when you were able to afford to buy a new house or you inherited parents' or grandparents' home. Therefore, for young Italians, contractual discontinuity was associated with the discontinuity of income and difficulty in accessing credit and home ownership, which was a system of protection against financial risk.

In the terms described above, we intend to deal with the repercussions on income and financial management that derives from this structure of integration, or lack of integration among the welfare system, the labour market and access to credit.

\subsection{The financialization of young Italians}

The role of the banking sector in shaping the opportunities of young Italians has evolved as a recent research interest, possibly because the involvement of families in the financial sector is relatively recent. In other terms, the credit market for families is underdeveloped in comparison to other countries: families have higher savings ${ }^{3}$ (Dagnes, 2010; Cannari and D'Alessio, 2006), and even after financial crisis they continue to save, except younger families (Banca d'Italia, 2018). Until recently, they showed higher levels of wealth in the form of property investment. Up until the Second World War, Italian families were less concerned with banking, or rather they benefited much less from banking products and services compared to today, and they were also not very indebted. In $1967,{ }^{4}$ the percentage of people in debt was $18 \%$, of whom only $15.2 \%$ had turned to a bank and $5 \%$ went to non-banking financial institutions. The main source of loans came from friends and family members; $31.7 \%$ of those who needed money used to do this. The percentage rose to $39.9 \%$ among low-income families, but remained above $20 \%$ in high-income families who preferred to turn to banks in $40 \%$ of cases. In addition, $40 \%$ of low-income people were in debt, and more than $20 \%$ of middle- and high-income borrowers had small debts with suppliers and retailers for purchases that were necessary to carry out their profession. There were also accounts opened by families at food shops or for consumer goods, including the first instalment-rate purchases. What is specific to the Italian context was the delay in starting the process of indebtedness. 
Over the years, the Italian context has changed. Since the 1990s, the stability of permanent contracts and the high financial solidity of Italian families in terms of savings on the one hand, and the start of the liberalization of the banking system with the Amato Law in 1992 on the other, have created favourable conditions for the growth of the mortgage market in Italy. Initially, small debts, accessed with the guarantee of family patrimony allowed Italian families to afford things in line with their desired lifestyle. However, the number of Italian families with a mortgage did not significantly change: lower than $5 \%$ in the 1960 s, and up to $5 \%$ in the 1990 s. In 2008 , indebted households rose to $27.8 \%$, of whom only $12.23 \%$ had debts with relatives and friends, even though after the financial crisis this trend seemed to have reversed (Banca d'Italia, 2010). The biggest change was related to the widespread access to mortgages amongst new generations: in the 2000s real estate debt had a greater weight in the financial liabilities of young people up to the age of 34 , especially if they were employed and graduates. The biggest changes took place after the deregulation of the 1990s: between 1998 and 2007 the money disbursed by banks to households for the purchase of a house rose by an average of $17 \%$ per year (Bonaccorsi di Patti and Felici, 2008). This was partly due to the growing number of households applying for a loan, and partly to the increase in the average loan value.

In a study carried out in the 1980s, Jappelli and Pagano (1988) found that the conditions for obtaining a bank loan in Italy disadvantaged young people. In the last 20 years, things have partially changed and the percentage of young people $^{5}$ out of the total of those who obtained a mortgage, went from $6.9 \%$ in 1989 to $15.4 \%$ in 2008 (Banca d'Italia, 2010). Such data confirm the changes in banking policy towards those categories of customers who were previously relatively less involved in the credit market. Following the deregulation in the 1990s, banks have been more likely to grant loans over longer time horizons or in more flexible ways. Therefore, families have borrowed through easier procedures than in the past. However, access to bank credit is not easy for everyone, and banks have certainly expanded access to credit, but they are not willing to give credit to families with no savings or other assets, especially following the 2007 financial crisis.

In this sense, the situation of the Italian banking sector in general, and of the credit sector, in particular, differs from the American one. In Italy, after the financial crisis, liabilities have amounted to $70 \%$ of disposable income compared to $100 \%$ in France and $132 \%$ in the United States, as mentioned previously. Looking at the spread of mortgages among households, the figure in Italy stood at $12.6 \%$, compared to an estimated $25 \%-30 \%$ in France, Germany and Spain, 35\%-40\% in Ireland and the Netherlands, and over 50\% in the United States (Banca d'Italia, 2010). From an institutional point of view, the Italian case presents factors with a contrasting effect on the growth of the mortgage sector for households (Jappelli et al., 2008). On the one hand, in relation to the European context, there is a high degree of information sharing on the financial history of customers, an element that helps to overcome uncertainty regarding 
the capacity of customers to pay back money, and therefore facilitates the sale of credit instruments, including mortgages, from the banks. On the other hand, the long-term framework of the Italian judicial system and the only recently filled gap in legislation regarding the bankruptcy of households has increased the cost of loans and, to some extent, limited the offer, because they make the recovery of credit by banks uncertain.

Banks have defined households that are still not in debt as an expanding market, and the Italian banking sector looks at the backwardness of the Italian credit market compared to the United States as a reservoir with high-growth potential. ${ }^{6}$ The inclusion of young people with atypical contracts, however, given the discontinuity of their income, is yet to come. Moreover, after the financial crisis of 2008, the credit crunch, the uncertainty regarding the economic situation and the new international regulatory frame about risk management in banking system did not support an increase in credit access.

In this direction, the Italian State has started to support the credit market, making financial funds as a guarantee for debt given by banks to individuals, especially young people, without the requested features. These funds are used only if young people are not able to cover their debts. ${ }^{7}$ Such measures were implemented at a national level, but also by some municipalities. However, the condition to access the protection of these funds still excludes atypical workers (Moiso, 2012).

\subsection{Coping strategies linked to work and salary}

It is useful to study the practices of family/individual management of money (spending, saving and investment) of young atypical workers in this difficult private and public institutional context, especially focusing on how housing costs are handled. There are many studies on young atypical workers but not many that look at their financial strategy. Using a life-course approach (Elder, 1985) of transitions, a study (Bertolini, 2012) reconstructed the working family and economic careers of women with permanent contracts and women with fixed-term contracts in Turin and Naples. The research showed that, at the same age and with the same qualifications, the aspect that most influenced financial decisions (house purchase, investments in additional pension schemes, etc.) and family life (leaving parents, marriage, cohabitation, first child, etc.) was the contractual form. Atypical workers were systematically a few years late in achieving their private and financial life milestones with respect to those with permanent employment contracts.

An essential point regards the interdependence between different careers and decisions. The atypical workers emphasized the difficulty or impossibility of planning their working careers and, as a consequence, their private lives from a long-term perspective. One of the effects of remaining in atypical employment was the postponement of important decisions in one's private life, as a wide range of literature has shown (Blossfeld et al., 2005). Having to suspend their 
plans with regard to their work also led to similar behaviour in other dimensions of their private lives. Our results showed that financial investments, such as buying a house or investing money, were also delayed, mainly due to the irregular income effect. Therefore, they lived with short-term planning:

I can identify comments regarding atypical workers: economic fragility... being treated like consultants, but paid possibly less than the others, makes any future planning difficult, the feeling of a continuous shaky situation, and in my opinion also psychological insecurity. (Paola, 33, training agency, degree in Science of Education, Turin)

Instability in terms of one's job also meant uncertainty about the continuity of income. Those with atypical contracts also suffered from the irregularity of payments. They were often paid at the end of a contract in a single lump sum, while the world they lived in was based on monthly deadlines.

With a lack of institutional protection, and the impossibility of being able to set up basic financial instruments, such as loans, atypical workers activated individual protection strategies. There were essentially two types: the first was precautionary saving; the second was asking their families for help. The first involved saving money without investing it for of fear of there being periods in which they would have no income:

As I don't have a permanent contract (also close to expiry), I also prefer not to take on any form of payment obligations that are too demanding, but in the long run I have realised that things tend to drag on... in the end, the solution I have adopted is to make temporary sacrifices, putting a bit of money aside and asking relatives for a loan, if possible, paying it back gradually. (Carmela, 28, classroom tutor, Naples)

Sometimes, this precautionary saving might have been excessive in relation to the actual possibility of experiencing periods without any money. However, the income uncertainty that stemmed from both the lack of guaranteed job continuity and possible delays in payment frequently blocked alternative actions of those workers who postponed investment decisions. This also concerned investing in a private pension fund, even though these were workers had a greater need to set one up. With regard to this, the study showed that when they were close to 40 years of age, atypical workers acquired a real awareness of their work situation and put into action other protective strategies against present and future risks: they made financial investments, stipulated additional social security arrangements, set up supplementary pensions or borrowed from banks during periods when they were waiting to be paid, or they were thinking about it. Furthermore, some of them had drawn up some solutions with their banks to cover late payments, as overdraft facilities or other more complex financial instruments. 
Asking their parents for help in the event of financial necessity was considered normal by the majority of youth involved in the study. For instance:

I am looking for a house with my boyfriend and we want to buy it, so we are looking at mortgages. At the moment, we are just getting started, also because (perhaps) we have found a house, but what prices! Luckily, we can get a mortgage without having to ask our parents to mortgage their home as they are helping us with a tidy initial sum ... but what a hassle! (Eleonora, 31, instructor, Turin)

Some participants, when prompted, mentioned the fact that in this way they were delaying their entrance into the adult world. There was also a risk of an increase in social inequality between those who had a family that could support them in buying a house or in arranging a mortgage and those who did not. In addition, those most likely to invest their savings in long-term assets, real estate or government bonds appeared to be stable workers.

Looking at attitudes towards saving, research findings do not necessarily converge: some research findings identified a greater propensity amongst atypical workers towards saving (Bertolini, 2012). Others showed a lower propensity for atypical workers to save (Musumeci, 2011). In this regard, it is helpful if we differentiate between types of saving. Atypical workers used the so-called precautionary saving, but the difficulty was in long-term saving, and it was precisely this type that atypical workers could not have. Precautionary saving was shortterm and was, by definition, fluid. Such savings were not investable, since they needed easy access to that money for use in emergencies. Permanent workers who could still count on their fixed monthly salary did not express as much of a need for this type of saving.

Here, once again, the relationship with the banking system emerged as crucial: without long-term savings there can be no investment. In fact, research (Musumeci, 2011) showed a lower propensity to invest amongst precarious workers, precisely because the prospect of discontinuity in employment, linked to income discontinuity, and prevented them from planning in the long run, especially with respect to their finances. However, this meant a lower return on one's money and a loss for banks in terms of possible investors. Precautionary savings stayed in bank accounts.

Another study (Paskov, 2011) showed there was lower propensity amongst atypical workers to invest in supplementary pensions, although they needed this more than most. Again, the pension system as it is, penalized those who had discontinuous payments or different funds. In this study, Paskov found that more than the objective labour market situation, the subjective dimension, that is the perception of job insecurity and the fear of becoming unemployed, played a role in financial decisions. Perceived labour-market insecurity reduced the chances of creating retirement savings in the liberal, conservative and southern welfare regimes. People who perceived labour markets as uncertain did not feel that they 
had the power to make future financial plans, and they were more concerned with thinking about the present (Moiso, 2017, 2018). It also showed they had lessor access to insurance products (home, life, accident, health, supplementary pension and child health).

\subsection{The progressive fall into uncertainty of young Italians}

It is interesting to compare the findings regarding job insecurity and economic and housing uncertainty emerged in the previously mentioned EXCEPT project to the study on work and money management strategies of the previous paragraph (Bertolini et al., 2018a, 2019; Baranowska-Rataj et al., 2018; Unt and Gebel, 2018). The differences in meanings, feelings and coping strategies related to the overlapping experiences of job and income insecurity, which resulted in increased uncertainty for young people compared to those described above. The dimension of money management emerged as crucial, but at the same time it was framed in a context confined to the family dimension and the present situation.

Regardless of one's age and level of education, the main coping strategy was removing expenses that the young people interviewed deemed to be less essential, such as holidays, unexpected purchases and expensive leisure activities, differing from the research results mentioned in the previous paragraph. Practices of containing expenses were not put in place to attain or maintain economic autonomy, but to manage the expenses for oneself while their daily life expenses were covered by the parents with whom they lived. The lack of economic autonomy was in fact strictly linked to the lack of housing autonomy, and it persisted also for those young people who had a job. In fact, while in the Italian sample of EXCEPT there were groups of people living in a poor household to which they contributed financially to domestic expenses, there was also a good share of young people who had never contributed to the family budget because of their parents' denial, and who had saved their money in order to leave the parental home, buy a car or pay for their free-time expenses.

Strategies of money management put in place by young people underlined that those interviewed were undergoing a shift of risk management from the social system to the individual (see Sennett, 1998; Bosco and Sciarrone, 2006; Negri and Filandri, 2010), driven by the problem of job insecurity. The majority of participants were not in a stable position in the labour market and experienced uncertainty with respect to their work and income in a non-linear way. Atypical contracts with irregular duration, periods of unemployment between contracts, non-paid or underpaid jobs and irregularity in payments were all elements that made budget management more complex. Therefore, feelings and perceptions about the individual risk had increased, and the present had become the frame in which decisions were made (Bertolini et al., 2018b).

Going deeper into the macro, meso and micro coping strategies aimed at maintaining economic autonomy (see Baranowska-Rataj et al., 2015), the EXCEPT findings showed some specificities for Italian young people in comparison to 
past generations, as well as their counterparts in other European countries. At a macro level, despite the fact that some European policies or recommendations had started to consider the financial solutions to improve the social situation of young people who faced labour market insecurities, none of the young participants had been involved in these types of policies. In particular, measures directed at facilitating access to credit could have been useful for some participants in supporting them in self-employment - starting a new professional activity, opening a shop, or becoming an entrepreneur. These were dreams for some of the young people but, for the moment, they totally avoided debt. For those who knew about the possibility of having access to a microcredit programme, it would have been be a second-step strategy; for the time being, the goal was to enter the labour market in a more stable way, and a relationship with the banking system was totally avoided. Participants justified this behaviour in reference to their great fear of falling into debt. Moreover, they were aware that in Italy vulnerable workers were more expensive (higher interest rates) and risky to employers.

At a meso level, economic support given by friends and relatives in EU countries characterized between $40 \%$ and $90 \%$ of the working poor (Perrin-Heredia, 2013b; Lazarus, 2016). The young participants confirmed this with respect to parental support (Bertolini et al., 2018b). For the majority of the participants, this situation led to a loss of housing autonomy, which was connected to a low level of independence in the management of housing expenses, domestic consumption and long-term savings.

At a micro level, going into high-risk debt, such as a credit card or not paying some expenses, choosing to pay only what could create short-term sanctions (Perrin-Heredia, 2013a), were not strategies implemented by the Italian participants. This stands in contrast to other European countries, where such strategies were more widespread. In Italy, parental economic support seemed to protect young people from potentially dangerous behaviour (see Rolando and Beccaria, 2018) and more general economic distress (Colombo et al., 2018). Saving emerged as the most-widespread behaviour. Moreover, the meaning and scope of saving was focused on the present and on individual needs. Young people saved to protect themselves in the event of job loss, including personal expenses such as modest leisure activities or car costs. It was short-term savings that allowed young people to cope with high job insecurity. For the youth who had left the parental home, saving was a short-term strategy finalized to survive, given the uncertainty of the duration of contracts, the periods of unemployment and the absence of an adequate system of income support.

To sum up, if we define financial vulnerability as the individual level of exposure to external events or mistakes in individual financial choices, it depends on the intertwines between context in which people live and the decisions they make (Moiso, 2012). Given the overlap between job and income insecurity, the young interviewees became more vulnerable overall from a financial point of view. However, the level of vulnerability was not equal for all young people at 
a similar position in the labour market but was influenced by a combination of their individual financial career or debt career, other individual careers such a professional one, the availability and level of parental support, and housing decisions. Above all, financial vulnerability made young people perceive their situation as being worse, by shaping their individual perception of job insecurity and increasing the related stress. In the absence of a protective system other than the informal support of parents, it could affect their decisions about the future, such as remaining in the family home.

\subsection{Conclusion}

In this chapter, we introduced the main characteristics of the macro context of the Italian labour market and credit systems, then we presented the main results of different research projects that were conducted on similar samples of young people who faced labour market insecurity. By analysing risks arising from the synchrony on employment and income discontinuity, it was possible to draw some conclusions on short- and long-term inequalities, considering the intertwining of labour market, welfare system and financial sector.

This perspective helped us to investigate in greater detail the impact of precariousness on when and how young people in Italy completed their passage to adulthood. Job insecurity increasingly affected the decisions of young Italians in terms of delaying the decision to leave the parental home, given the increased uncertainty on the labour market mainly as a result of income insecurity. Until then, those with wealthy families with savings had been sheltered in terms of access to work, since they were able to implement a strategy of waiting to leave home only when they attained their first stable job.

This configuration risks being unsustainable in the future. Today, we are already witnessing a generation that has no aspirations for social mobility, and who at most aspire to maintain their positions. In addition, many risks are expected for the future pensions of this generation, given the impossibility of long-term savings. The long-term consequences of this situation are also defined in terms of career development with gender difference in resilience, accumulation and intergenerational transmission of economic resources.

Our discussion reveals the presence of new bottom-up strategies based on money management, not supported by institutions (welfare state or banks). It generates further inequalities among precarious workers, engendering a virtuous or vicious cycle. For now, studies have shown that, thanks to their parental economic support, young Italians have generally not entered into a vicious cycle of over-indebtedness.

At a macro level, measures to help workers to deal with the synchrony of employment and income discontinuity have only been introduced in Italy in recent years, following a much more widespread European trend (OECD and EU guidelines). However, fully fledged policies are still lacking. In 2018, the Italian government started a process of introducing a minimum income scheme. The recipients 
should benefit from an 18-month transfer, provided their availability to be involved in some active labour-market policies and immediate willingness to work.

In this context, a final question arises: would a national policy of easier access to credit help to improve the social situation of young people, who face labourmarket insecurities without support from the welfare state? According to the European Commission (2012: 3), credit of small amounts is an 'effective financing channel for job creation and social inclusion'. However, among the young people interviewed, credit was simultaneously seen as an opportunity and a risk. From an analytical point of view, the main risk is that of increasing the financial vulnerability of young people by allowing them easier access to credit. That is, if it were carried out without strong protection from the risk of default, given the predatory behaviour of banks and the potential lack of financial knowledge on the part of young people. On the contrary, we envisage policies aimed at enabling rather than providing, that is measures aimed at establishing a synergic collaboration among labour policies, social protection system, banking regulations and policies to support individual entrepreneurship, together with support for non-bank operators, especially non-profit. The latter have the appropriate experience to help the beneficiaries to put their skills into practice thanks to the loans received. This scheme has to be completed by a regulation directed at the protection of over-indebted subjects that provide forms of assistance in managing and restructuring personal debts.

\section{Notes}

1 All semi-structured interviews were recorded, fully transcribed and analysed according to a defined analytical framework. The first research was the project 'Online training for the development of women's managerial skills. Women Online' carried out by Cirsde in collaboration with Poliedra and Studio Staff, and financed by the Ministry of Labour and Social Policy. A sample made up of 50 young women aged between 25 and 40, with medium-high educational qualifications, mostly degrees or postgraduate specializations, in humanities, residing in Turin and Naples. These were women who worked in the business services sector. Two-thirds of them had atypical contractual forms, $\mathrm{CoCoCo}$ or CoCoPro (term-contract workers or professionals), and one-third were typical indefinite time workers. The different careers were reconstructed through the reorganization of the data in a reading grid on the model used from life-course research. The second research was the H2020 project 'Social Exclusion of Youth in Europe: Cumulative Disadvantage, Coping Strategies, Effective Policies and Transfer - EXCEPT' (2015-2018), involving nine countries: Bulgaria, Estonia, Germany, the United Kingdom, Greece, Italy, Poland, Sweden and Ukraine in a mixed-method research study on 400 young people. The Italian sample comprised 50 interviews conducted between December 2015 and November 2016. Samples covered people aged 18-30, balanced by gender and level of education ( 25 men and 25 women); 25 were aged 18-24, while the other 25 were $25-30$. Regarding their educational level, 26 out of 50 interviewees had a secondary level of education (ISCED 3, and only one ISCED 4), 12 had a low educational level (ISCED 0-2) and 12 had a tertiary education (ISCED 5-6). Other information can be found on www. except-project.eu. 
2 These limitations currently imply long-standing consequences, that is in relation to pensions: atypical workers have less opportunities to have access to complementary pension plans (Hofäcker et al., 2016; Moiso, 2018).

3 More data is available in the Bank of Italy documents, Survey on Household Income and Wealth.

4 All data is from the Bank of Italy, 'Survey on the Budgets of Italian Families - 1965-2008'.

5 Heads of family are under the age of 35.

6 From the talk by Giuseppe Zadra, then Director General of ABI (Italian Banking Association), at the conference Credito alle famiglie (Credit to Families) 2009, Rome, 23-24 June 2009.

7 For example, the funds for access to home mortgage for young couples or the funds for loans to households with newborn children, both of the Department for Family Policy of the Presidency of the Council of Ministers in 2011.

\section{References}

Aalbers, M.B. (2008). The financialization of home and the mortgage market crisis. Competition \& Change, 12(2), 148-166.

Banca d'Italia. (2010). I bilanci delle famiglie italiane nell'anno 2008 (Survey on Household Income and Wealth-year 2008). Roma: Banca d'Italia.

Banca d'Italia. (2018). I bilanci delle famiglie italiane nell'anno 2016 (Survey on Household Income and Wealth- year 2016). Roma: Banca d'Italia.

Bandelj, N., Wherry, F. and Zelizer, V. (eds) (2017). Money Talks: Explaining How Money Really Works. Princeton and Oxford: Princeton University Press.

Baranowska-Rataj, A., Bertolini, S., Ghislieri, C., Meo, A., Moiso, V., Musumeci, R., Ricucci, R. and Torrioni, P. (2015). Becoming Adult in Hard Times: Current and Future Issues on Job Insecurity and Autonomy. Torino: Academia University Press.

Baranowska-Rataj, A., Bertolini, S. and Goglio, V. (eds) (2018). Country level analyses of mechanisms and interrelationships between labour market insecurity and autonomy. EXCEPT Working Papers, 11, Tallinn: Tallinn University Press, http://www.exceptproject.eu/working-papers.

Barbieri, P. and Scherer, S. (2009). Labour market flexibilization and its consequences in Italy. European Sociological Review, 25(6), 677-692.

Bertolini, S. (2011). The heterogeneity of the impact of labour market flexibilization on the transition to adult life in Italy: When do young people leave the nest? In: Blossfeld, H.P., Hofäcker, D. and Bertolini, S. (eds) Youth on Globalised Labour Markets: Rising Uncertainty and Its Effects on Early Employment and Family Lives in Europe. Opladen \& Farmington Hills: Barbara Budrich, 163-187.

Bertolini, S. (2012). Flessibilmente giovani. Percorsi lavorativi e transizione alla vita adulta nel nuovo mercato del lavoro (Flexibly young. Job careers and transition to adult life in the new labour market). Bologna: il Mulino.

Bertolini, S., Hofacker, D. and Torrioni, P. (2014). L'uscita dalla famiglia di origine in diversi sistemi di Welfare State: l'impatto della flessibilizzazione del mercato del lavoro e della crisi occupazionale in Italia, Francia e Germania (The exit from the family of origin in different welfare state systems: The impact of labour market flexibility and the employment crisis in Italy, France and Germany). Sociologia del lavoro, 136, 144-125.

Bertolini, S., Deliyanni-Kouimtzi, K., Bolzoni, M., Ghislieri, C., Goglio, V., Martino, S., Meo, A. et al. (eds) (2018a). Labour market insecurity and social exclusion: Qualitative 
comparative results in nine countries. EXCEPT Working Paper, 53, Tallinn: Tallinn University Press, http://www.except-project.eu/working-papers.

Bertolini, S., Moiso, V. and Musumeci, R. (2018b). The Italian Report: Young adults in insecure labour market positions - The results from qualitative studies. EXCEPT Working Papers, 18, Tallinn: Tallinn University Press, http://www.except-project.eu/ working-papers.

Bertolini, S., Moiso, V. and Unt, M. (2019). Precarious and creative: Youth facing uncertainty in the labour market. In: Colombo, C. and Rebughini, P.A. (eds) The Politics of the Present. London: Routledge (forthcoming).

Berton, F., Richiardi, M. and Sacchi, S. (2009). Flexinsecurity: perché in Italia la flessibilità diventa precarietà' (Flexinsecurity: Why flexibility becomes precariousness in Italy). Bologna: il Mulino.

Blossfeld, H.P., Buchholz, S., Hofacker, D. and Bertolini, S. (2012). Selective flexibilization and deregulation of the labor market: The answer of Continental and Southern Europe. Stato e Mercato, 96, 364-390.

Blossfeld, H.P., Hofäcker, D. and Bertolini, S. (eds) (2011a). Youth on Globalised Labour Market: Rising Uncertainty and Its Effects on Early Employment and Family Lives in Europe. Opladen (Germany) and Farmington Hills (USA): Barbara Budrich Publishers.

Blossfeld, H.P., Hofacker, D., Rizza, R. and Bertolini, S., (2011b). Giovani, i perdenti della globalizzazione? (Young People, Globalization's Losers?). Sociologia del lavoro, 124.

Blossfeld, H.P., Klijzing, E., Mills, M. and Kurz, K. (eds) (2005). Globalization, Uncertainty and Youth in Society. London: Routledge.

Bologna, S. and Banfi, D. (2011). Vita da freelance. I lavoratori della conoscenza e il loro futuro, Milano: Feltrinelli. [Freelance life. Knowledge workers and their future].

Bonaccorsi di Patti, E. and Felici, R. (2008). Il rischio dei mutui alle famiglie in Italia: evidenza da un milione di contratti (The risk of mortgages to families in Italy: Evidence from one million contracts). Banca d'Italia Occasional papers, 32. Roma: Banca d'Italia.

Bosco, N. and Sciarrone, R. (2006). La certezza dell'incertezza. Ambivalenze e rimedi, Meridiana, 55, 9-33 [The certainty of uncertainty. Ambivalences and reliefs].

Buchholz, S., Höfacker, D., Mills, M., Blossfeld, H.P., Kurz, K. and Hofmeister, H. (2009). Life courses in the globalization process: The development of social inequalities in modern societies. European Sociological Review, 25(1), 53-71.

Cannari, L. and D’Alessio, G. (2006). La ricchezza degli Italiani (The wealth of Italians). Bologna: il Mulino.

Colombo, E., Leonini, L. and Rebughini, P. (2018). A generational attitude: Young adults facing the economic crisis in Milan. Journal of Modern Italian Studies, 23(1), 61-74.

Crompton, R. (2000). Renewing Class Analysis. Oxford: Blackwell.

Dagnes, J. (2010). Il requisito della ricchezza (The wealth requirement). In: Negri, N. and Filandri, M. (eds) Restare di ceto medio. Il passaggio alla vita adulta nella società che cambia. Bologna: il Mulino.

Deville, J. and Seigworth, G. (2015). Everyday debt and credit, introduction to special issue. Cultural Studies, 29(5-6), 615-629.

Ducourant, H. (2014). Why do the poor pay more for their credit? A French case study. In: Guérin, I., Morvant-Roux, S., Villareal, M. (eds) Microfinance, Debt and OverIndebtedness. London: Routledge.

Elder, G.H. Jr. (ed) (1985). Life Course Dynamics: Trajectories and Transitions, 1968 1980. Ithaca, New York: Cornell University Press. 
European Commission. (2012). Report from the Commission to the European Parliament and the Council on the application of Directive 2006/48/EC to microcredit, 18 December 2012, COM(2012) 769 final, Available at: https://ec.europa.eu/transparency/regdoc/rep/1/2012/EN/1-2012-769-EN-F1-1.Pdf.

Flaherty, J. and Banks, S. (2013). In whose interest? The dynamic of debt in poor households. Journal of Poverty and Social Justice, 21(3), 219-232.

Fourcade, M. and Healy, K. (2013). Classification situations: Life-chances in the neoliberal era. Accounting, Organizations and Society, 38(8), 559-572.

Hofäcker, D., Hess, M. and König, S. (eds) (2016). Delaying Retirement: Progress and Challenges of Active Ageing in Europe, the United States and Japan. Basingstoke: Palgrave Macmillan.

Jappelli, T. and Pagano, M. (1988). Liquidity-Constrained Households in an Italian CrossSection. Cepr Discussion Paper 257.

Jappelli, T., Pagano, M. and di Maggio, M. (2008). Households' Indebtedness and Financial Fragility. Centre for Studies in Economics and Finance (CSEF) Working Papers 208.

Lacan, L., Lazarus, J., Perrin-Heredia, A. and Plot, S. (2009). Vivre et faire vivre à crédit: agents économiques ordinaires et institutions financières dans les situations d'endettement. Sociétés contemporaines, 76(4), 5-15.

Langley, P. (2009). The Everyday Life of Global Finance. Oxford: Oxford University Press.

Lazarus, J. (2016). Le tissage de notre vie quotidienne et de la finance. In: Chambost, I., Lenglet, M. and Tadjeddine, J. (eds) La Fabrique de la finance. Paris: Presses Universitaires du Septentrion.

Lazarus, J. and Luzzi, M. (2015). Les pratiques monétaires des ménages au prisme de la Financiarization. Critique internationale, 69(4), 9-19.

Martin, R. (2002). Financialization of Daily Life. Philadelphia: Temple University Press.

Mckee, K. and Hoolachan, J. (2015). Housing generation rent: What are the Challenges for Housing Policy in Scotland? Working paper of Centre for Housing Research University of St Andrews.

Meo, A. and Moiso, V. (2018). Precari e autonomi: un binomio (im)possibile (Precarious and autonomous: a (im)possible pair). In: S. Bertolini (ed) Giovani senza futuro? Insicurezza lavorativa e autonomia giovanile nell'Italia di oggi. Roma: Carocci.

Mills, M. and Blossfeld, H.P. (2003). Globalization, uncertainty and changes in early life courses. Zeitschrift für Erziehungswissenschaft, 6(2), 188-218.

Moiso, V. (2012). L'accesso al credito come innovazione di welfare e contrasto alla vulnerabilità (Access to credit as a welfare innovation and contrast to vulnerability). Rivista delle Politiche Sociali, 4, 313-332.

Moiso, V. (2017). Country case - Italy. In: Hofäcker, D., Schadow, S. and Kletzing J. (eds) Long-Term Socio-economic Consequences of Insecure Labour Market Positions. Tallin: Tallin University Press, 77-88.

Moiso, V. (2018). (Im)previdenti? Rappresentazioni e strategie di giovani precari sulle pensioni ((Im)foresighted? Representations and strategies of precarious young people on pensions). In: Caselli, D. and Dagnes, J. (eds) Autonomie Locali e Servizi Sociali - session on 'Salvati dalla finanza? Finanziarizzazione, welfare e benessere', 2, 271-288.

Montgomerie, J. (2009). The pursuit of (past) happiness? Middle-class indebtedness and American financialisation. New Political Economy, 14(1), 1-24. 
Musumeci, R. (2011). Consumi di giovani adulti catanesi, Instabilità del lavoro e razionalità nelle decisioni di acquisto, (Consumption of young people from Catania, labor instability, and rationality in purchasing decisions). Roma: Aracne.

Negri, N. and Filandri, M. (2010). Restare di ceto medio. Il passaggio alla vita adulta nella società che cambia. Bologna: il Mulino.

Ossandón, J. (2014). Sowing consumers in the garden of mass retailing in Chile. Consumption Markets \& Culture, 17(5), 429-447.

Paskov, M. (2011). Labour market uncertainty and Private Pension planning in Europe. In: Blossfeld, H.P., Hofäcker, D. and Bertolini, S. (eds). Youth on Globalised Labour Market. Rising Uncertainty and Its Effects on Early Employment and Family Lives in Europe. Opladen, Germany and Farmington Hills, MI: Barbara Budrich Publishers.

Perrin-Heredia, A. (2011). Faire les comptes: normes comptables, normes sociales. Genèses, 84(3), 69-92.

Perrin-Heredia, A. (2013a). Le choix en économie. Le cas des consommateurs pauvres. Actes de la recherche en sciences sociales, 199(4), 46-67.

Perrin-Heredia, A. (2013b). La mise en ordre de l'économie domestique. Gouvernement et action publique, 2, 303-330.

Rabaiotti, D. (2011). La casa come un servizio, Dossier Centro servizi per il volontariato nella provincia di Milano, 2, settembre 2011.

Rolando, S. and Beccaria, F. (2018). Young people and drinking in Italy: The good side of familism. Journal of Modern Italian Studies, 23(1), 93-107.

Sennett, R. (1998). The Corrosion of Character. The Personal Consequences of Work in the New Capitalism. New York and London: W.W. Norton \& Company.

Unt, M. and Gebel, M. (eds) (2018). Synthesis of the main empirical findings of EXCEPT project. EXCEPT Working Paper, 57, Tallinn: Tallinn University Press, http://www. except-project.eu/working-papers.

Zelizer, V. (1994). The Social Meaning of Money. New York: Basic Books. 